\title{
2008-E-12
}

\section{Competitive Regionalism and Mexico's FTA Strategy}

\author{
Aldo Flores-Quiroga \\ Assistant Professor at the School of Politics and. Economics \\ the Claremont Graduate University
}

June 2008

Paper presented at the International Symposium "Competitive Regionalism," Ibuka International Conference Hall, Waseda University, Tokyo, Japan. May 30 to 31, 2008. 


\section{Competitive Regionalism and Mexico's FTA strategy Aldo Flores-Quiroga}

\section{Draft. May 16, 2008.}

\section{Introduction}

There are two distinct phases to Mexico's modern trade strategy, each representing a different approach to multilateral and bilateral trade negotiations. The first phase, covering from 1970 to 1985, is characterized by two failed attempts at opening the trade regime unilaterally, including an unsuccessful effort to join the GATT at the end the Tokyo Round in 1979 due to domestic political pressures. During this phase the country's economic strategy was inward oriented, and regionalism was not high in the priorities of Mexican policymakers.

The second phase, from 1986 to date, combines unilateral trade liberalization, accession to the GATT, and the signing of thirteen FTAs with countries in the Western Hemisphere, Europe, the Middle East, and Asia. It includes Mexico's formal entrance as a full member of APEC and the OECD. It is when competitive regionalism became a central component of a new outwardoriented strategy.

The transition from one phase to the next is usually explained in terms of the collapse of the strategy of industrialization through import-substitution (ISI) in $1982,{ }^{1}$ but can also be seen as part of a broader trend of greater formalization of Mexico's increasing economic relations with the world. This trend began to

\footnotetext{
${ }^{1}$ A large body of literature has already done this. See for example
} 
take shape in the early 1970s, when trade represented about $20 \%$ of Mexican GDP, and consolidated by the late 1990s, as this proportion reached close to $60 \%$.

Throughout this period Mexico signed a larger number, and geographically disperse, set of economic agreements than before, ranging from bilateral investment protection, double taxation, financial and customs cooperation, and promotion, limited preferential trade concessions, and fullfledged free trade.

The extent to which the formalization of international economic exchanges through legal documents was a result or a cause of a greater level of international economic intercourse is subject to debate, but there is little doubt that the arrival of regionalism in Mexico is part, if not the expression, of this internationalization trend. Greater trade and investment flows required a greater degree of policy coordination, or at least, collaboration, with the country's main trade and investment partners, most notably the United States (US). As the requirements for coordination increased, the scope of the agreements also increased, until limited engagement gave way to greater integration under the terms of a Free Trade Agreement (FTA).

From this broad review one might rightly conclude that functionalism explains much of the action behind Mexican international economic policy choices, but it is only a beginning. The story behind Mexico's choice of trading partners does not correlate perfectly with the intensity of economic exchange. While a broad correspondence between these two factors does exist, deviations are also apparent, associated with non-economic factors. 
To understand these choices it is necessary to go beyond purely economic, or functional, explanations for regionalism. The drive to emulate countries in North America and Europe who were implementing successful integration policies, as well as countries in Asia which achieved high economic grouth rates through export promotion, supported the Mexican government's decisions in its effort to sell Mexico as a good destination for foreign investors, among other objectives. The private sector's concerns over its competitiveness, in light of integration initiatives north of the Mexican border, derived into active lobbying, and thus influenced policy shifts in the direction of free trade.

Accounting for Mexico's sequential choice of trade partners, and of eventual success in reaching a FTAs, requires paying attention to the international economic, political and legal environment in which it has been immersed, with an eye to the challenges that have guided its foreign policy toward its neighbors. It requires as well paying attention to developments in the domestic arena, for Mexico adopted the strategy of competitive regionalism to advance its own domestic reform agenda, not exclusively to accomplish foreign policy objectives.

\section{A review of Mexico's trade negotiations, 1970-2005}

Table 1 presents Mexico's thirteen FTAs to date in chronological order, covering a total of 43 countries:

\section{Table 1. Chronology of Mexico's Free Trade}




\begin{tabular}{|c|c|}
\hline \multicolumn{2}{|c|}{ Agreements } \\
\hline Year & FTA \\
\hline 1992 & 1. Chile \\
\hline 1994 & 2. NAFTA (United States and Canada) \\
\hline 1995 & $\begin{array}{l}\text { 3. G3 (Colombia and Venezuela) } \\
\text { 4. Bolivia } \\
\text { 5. Costa Rica }\end{array}$ \\
\hline 1998 & $\begin{array}{l}\text { 6. Uruguay } \\
\text { 7. Nicaragua }\end{array}$ \\
\hline 2000 & $\begin{array}{l}\text { 8. European Union (15) } \\
\text { 9. Israel }\end{array}$ \\
\hline 2001 & $\begin{array}{l}\text { 10.EFTA (Norway, Iceland, Switzerland, } \\
\text { Lichtenstein) } \\
\text { 11.Northern Triangle of Central America } \\
\text { (Guatemala, Honduras, El Salvador) }\end{array}$ \\
\hline 2004 & 12.European Union $(15+12)$ \\
\hline 2005 & 13.Japan \\
\hline
\end{tabular}

The table refers to the year in which agreements were signed, not to the date in which negotiations started. It does not include negotiations under way as of this writing, ${ }^{2}$ with Peru and South Korea, or suspended ones, with Ecuador or Panama (the reasons are explained below). It excludes potential negotiations, for which prospective discussions have started but have not materialized into the beginning of negotiations, for example with New Zealand or Australia. Were the beginning of negotiations the preferred criterion for constructing the table, the first agreement in the list would have been NAFTA, which launched Mexico's FTA strategy.

The first pattern to emerge is that between 1992 and 1999 Mexico signed FTAs only with countries in the Western Hemisphere: with the United States and Canada to the North, and with a number of Latin American countries to the South. The latter include three who belong to the Andean Pact (Venezuela,

2 October 2007. 
Colombia, and Bolivia, but not Ecuador or Perú), Chile, two in Central America (Costa Rica and Nicaragua), and one member of Mercosur (Uruguay). No Caribbean country signed an FTA with Mexico, nor did any other country from the Southern Cone.

The absence of an FTA with the remaining countries of Latin America does not imply lack of interest, however. Negotiations with all of them either started, or were proposed, by the mid 1990s. As with the successful FTAs, all of the negotiations occurred under the framework of the Latin American Association for Integration (Asociación Latinoamericana de Integración, or ALADI), a regionwide agreement that allows for the signing of FTAs without the need for a ratification procedure in national parliaments. ${ }^{3}$ Negotiations with the countries of the Northern Triangle of Central America were underway and eventually concluded in 2001. For practical purposes they can be included in this block of Latin American countries that signed FTAs with Mexico. Negotiations with Panama, Ecuador, and Peru started in tandem with the others, but were stalled or suspended by 1998. And negotiations with the other countries of Mercosur have been contemplated, but have not moved beyond an agreement on the automobile industry.

So by the close of the 1990s Mexico had signed FTAs with all its neighbors, except for Cuba and other countries with which it shared maritime borders.

\footnotetext{
3 ALADI was founded under in the early 1960s under the name Asociación Latinoamericana de Libre Comercio (ALALC, or Latin American Free Trade Association). ALADI simplifies the process of signing FTAs within the region because they only need to be signed by the Executives of the signatory countries, not by their legislatures In the 1970s the "Libre Comercio," or free-trade part of the name lost favor among many of its members, so the more neutral, current, name was adopted.
} 
The year 2000 inaugurates the era of Mexico's cross-regional agreements, with the signature of the FTAs with the European Union (EU15, expanded to EU27 by 2006) and Israel, followed by the agreement in 2001 with European Free-Trade Area (Norway, Switzerland, Lichtenstein, Iceland).

It was not until 2005 that Asia entered Mexico's portfolio of FTAs, through the completion of negotiations with Japan. Japan, however, was not the first Asian country to consider negotiating an FTA with Mexico; Singapore took the leading role. Today Singapore is not negotiating an FTA with Mexico, but South Korea is.

\section{Understanding Mexico's FTA strategy}

To assess which of the three hypotheses analyzed in this book - null (independent decisionmaking), emulation, and competition- carries more explanatory potential, we can start by considering objectives frequently identified behind Mexico's FTA strategy: 4

1. Securing stable access to the country's main export markets.

2. Reducing trade diversion caused by other countries' FTAs.

3. Mitigating investment diversion effects of other FTAs.

4. Increasing access to low-cost inputs to improve competitiveness.

5. Diversifying exports.

\footnotetext{
4 The literature is, again, vast. See, for example, Blanco (), Flores Quiroga (1998)...
} 
6. Promoting coalitions of like-minded countries in multilateral trade talks.

7. Promoting sub-regional political alliances.

8. Increasing the cost of trade-reform reversals -increasing the credibility of trade liberalization.

9. Establishing a credible legal regime for investors.

10. Reducing inflationary pressures.

11. Loosening the grip of dominant local economic and political groups.

For the null hypothesis to hold, objectives 2 and 3 would have to be removed from the list; probably 6 and 7 as well. But, as discussed in the next section, considerable evidence on the timing of decisions, as well as numerous remarks and testimonies from government officials and business leaders, shows that NAFTA was proposed in reaction to international developments, especially the nascent wave of regionalism in Europe and North America. ${ }^{5}$ And Mexican authorities negotiated succeeding FTAs, among other reasons, to avoid extreme export concentration on just one market, consolidate competitiveness gains derived from access to low-cost inputs, and even to promote regional development - all of these related to international strategic calculations. Domestic factors, while absolutely indispensable for a successful explanation of Mexico's adoption of free trade, cannot on their own account for the decision to pursue it through FTAs.

${ }^{5}$ A detailed review of that evidence can be found in Flores-Quiroga (1998). The discussion that follows summarizes some of the most relevant aspects. 
We are left with the emulation and competition hypotheses. Which is more plausible? The answer is necessarily ambiguous, considering that the main drivers of Mexico's FTA approach are consistent with both. The rest of this chapter explains why.

\section{Mexico's Competitive Regional Strategy Begins}

The trigger for the Mexican government's decision to propose the negotiation of an FTA with the United States - its first FTA venture- involves a shift in the international strategic environment which, combined with the transformation of Mexican trade policy and politics throughout the 1980s, increased the opportunity cost of not joining a regional trade area.

Two international factors are most relevant: the launch of the US-Canada FTA and the fall of the Berlin Wall, both occurring in $1989 .{ }^{6}$ The first mobilized the members of the country's pro-export lobby in favor of an FTA with the United States. The second added weight to their arguments with respect to importcompeting interests, tipping the government's hand toward a proposal for a USMexico FTA.

As soon as the US-Canada Free Trade Agreement (USCFTA) entered into full force in J anaury 1989, Mexico's outward-oriented entrepreneurs and their partners in the United States expressed their concern that trade and investment flows would be diverted away from Mexico. This was the message the head of the

6 The USCFTA was signed in 1988; it started operating on J anuary 1, 1989. The free crossing of Easter European citizens through the Berlin Wall started on November 9, 1989. 
international arm of Mexico's peak business association, the Foreign Affairs Business Council, told the Mexican president at its annual meeting, with the joint recommendation of negotiating a similar free trade agreement with the United States and softening the laws on foreign investment. ${ }^{7} \mathrm{He}$ echoed a recommendation that for at least two years the Mexico-US Business Committee (MUSBC), a prominent bi-national group of businesspersons and academicians, had been advocating, as negotiations for the USCFTA were under way. The group's argument is worth quoting, even if long, for it summarizes the position of Mexico's pro-export "lobby" -a loose amalgam of the country's wealthiest businessmen, multinational corporations, and associations representing exporters and importers- regarding the issue of regional free trade, which they linked with the issue of policy certainty:

"Confidence attracts capital. Investor confidence is based on dependable, satisfactory expectations about the business environment. In Mexico, legal uncertainty reduces the level of confidence and inhibits long-term investment.

The frequent amending of Mexican laws and regulations affecting trade and investment causes a serious lack of confidence among private investors. In Mexico, the legal order and the institutions that support it should be strengthened and given permanence and stability. Of paramount importance are (1) narrowing the discretionary authority of the government as it pertains to private investment, commerce, and the operations of productive enterprise, and (2) increasing the rights conferred by law on investors. The

TExcélsior (February 8, 1989). Other businessmen held the same view: a survey conducted during the first half of 1989 revealed that 64 of 100 Mexican manufacturers favored negotiating a free trade agreement with the United States (del Castillo, 1989). 
objective for the Mexican economy should be to reduce the scope of regulation of the private economy....The government's wide discretionary powers hamper sound economic management in Mexico. The private economy will feel at risk until it is manifest that there is a long-term commitment to free major parts of the economy from government administration and detailed regulation...

...Adherence by Mexico and the Unites States to the principles of free trade will contribute to create the indispensable trust for long-term private direct investment in modern factories...[the MUSBC recommends] a careful study of the trade agreement between the United States and Canada since it will, together with a bilateral agreement between Mexico and the United States, constitute the basis for increasing the volume of trade and investment between Canada, the United States, and Mexico. This future trilateral relationship will strengthen North America's competitiveness in an era of global markets." 8

By March and J une 1989, the MUSBC was also proposing specific options for liberalizing U.S.-Mexico trade and investment, contemplating both limited and wide-ranging trade and investment agreements. ${ }^{9}$

The link the MUSBC made between an FTA and a credible investment regime, so that "the principles of free trade will contribute to create the indispensable trust for long-term private direct investment" derived from recent Mexican experience. Attempts at economic restructuring in the 1970s and 80s had shown Mexican institutions incapable of sustaining a lowering of trade

8Mexico-U.S. Business Committee (1987), p. 9, 11, and 13. Translated from Spanish, my emphasis added. This is an extension of the concepts that other business associations, most notable the influential employers union, COPARMEX, and the peak business association, CCE, which encompasses all other associations, had advanced in previous years.

9See Mexico-United States Business Council (1989a; 1989b). 
barriers. As soon as the current account deteriorated, even if the proximate cause was an overvalued exchange rate, itself caused by a burgeoning fiscal deficit, Mexican authorities reversed course and increased tariffs. And as soon as fiscal deficits reached crisis proportions, the government was quick to expropriate wealth from private investors. Regionalism, from the perspective of this freetrade lobby, helped to avoid this outcome because it required the signing of international contracts that fixed domestic policy and could be reneged only at a very high cost. ${ }^{10}$ Regionalism would work as an anchor for domestic policy reforms, increasing trust in their long-term sustainability, while generating incentives for attracting long-term investments.

But the Mexican president at the time, Carlos Salinas, was not yet persuaded. As he told these business leaders upon learning of their proposal, Mexico was not going join any international economic bloc; it would only search to secure the access of Mexican goods in foreign markets through limited tariff concessions. Economic stability and a similar level of development with a target partner, from his perspective, were preconditions for even contemplating the negotiation of an FTA. ${ }^{11}$

Salinas had another important reason to wait: during 1989 the most pressing priority for his government was to renegotiate the terms of its foreign

\footnotetext{
10 A country that does not respect its international commitments faces the risk losing potential partners. This represents a reputation cost. To avoid this outcome, the traditional practice is to make international agreements the law of the land. This represents another cost, for the justification for reneging on an international agreement is that germane constitutional provisions have changed.
}

${ }^{11}$ He had advanced this argument during his presidential campaign in 1988, and was the position with which he took office (Flores Quiroga, 1998). 
debt payments, ${ }^{12}$ not to enter into a controversial free-trade arrangement with the country's neighbors, or anyone else. To negotiate an FTA while renegotiating one of the most ambitious debt-restructuring and discounting packages ever ${ }^{13}$ would only complicate matters and create unnecessary issue linkages between both negotiation routes. This much he had in mind, at least, when as presidentelect he rejected a tentative proposal of George H.W. Bush, then also presidentelect, to begin negotiations for a US-Mexico FTA. ${ }^{14}$

The Mexican president opted instead for an international economic strategy combining four components: in addition to foreign debt renegotiation, attraction of foreign direct investment, expansion of preferential trade access to Europe, and management of US-Mexico trade through sectoral agreements. The first two were meant to improve the country's foreign accounts, under severe strain as an appreciating exchange rate, which was the basis of the antiinflationary policy, caused import growth to outstrip exports. The third aimed at reducing the strong dependence of Mexican exports on the US market, not only for its own sake, but because US trade sanctions had been increasing steadily. And the fourth sought to continue the policy of facilitating access in the US for sectors heavily involved in intra-industry trade (automobiles, autoparts), or with strong export potential (steel, chemicals, textiles). Sectoral agreements were the

\footnotetext{
12 It was the renegotiation of the government's debt payments, which had been suspended in 1982, when Mexico's internacional reserves had been depleted. This episode was the beginning of the internacional debt crisis and led to economic restructuring throughout Latin America. A synthetic, yet in-depth account of this renegotiation can be found in SHCP ().

${ }^{13}$ This negotiation led to the launch of the Brady Plan in late 1989, which for the first time accepted two important principles: (1) the totality of the foreign debts of Latin American countries would not be repaid, therefore they had to be reduced or discounted, and (2) without economic growth the prospects for debt repayment were nil.

${ }^{14}$ Salinas (2002).
} 
closest policy to bilateral free-trade, in light of the existing policy regime. ${ }^{15}$ The approach to Europe had a similar objective, but it also sought to further political links to counterbalance the strong influence of the United States.

Alas, it was a short-lived approach. Soon after the Berlin Wall fell in November 1989 Salinas discovered it was going to become increasingly difficult to attract investments from Western Europe, now focused on the opportunities Eastern Europe could offer. When he floated his ideas for a closer trade and investment relationship with his European peers he found little enthusiasm. The feedback he obtained in meetings with the Margaret Thatcher, Helmut Kohl, and J acques Delors, among others, echoed the same message: Europe is interested in building its own union; its interest in Mexico as an investment destination would increase only if it were part of a North American trade block. Further confirmation of this position came at the 1990 World Energy Forum in Davos, when Salinas noted in one conversation after another that it was harder to persuade governments and investors that Mexico was an attractive investment destination. 16

Salinas therefore decided to move forward with the proposal he had already heard from Mexican and US businessmen, European leaders, the US president, to join the North American trade block. By jumping into the regional bandwagon, he believed, Mexico would regain lost ground on the international

\footnotetext{
15 These agreements were negotiated in...

16 See president Carlos Salinas de Gortari's own account of these events in his book Mexico: el difícil paso a la modernidad.
} 
competition for investments. ${ }^{17}$ Still at Davos, he instructed his Trade Secretary to express to his US counterpart Mexico's interest in negotiating an FTA. A few weeks later key Mexican and US officials were meeting secretly to discuss how to proceed.

When the news broke out and Canada, fearful that it would lose some of the advantages it had obtained through the USCFTA, requested trilateral negotiations. By the fall of 1990 the three countries were ready to negotiate the creation of the largest free trade area in the world.

Up to here the story of Mexico's decision to negotiate an FTA involves competition for foreign direct investment as a channel of policy diffusion, with Mexico responding to the integration initiatives of its two main trading partners, Western Europe and the US, by joining the North American regional block. There is also a suggestion that the decision involves more than top-down decisionmaking: while the Mexican president did choose in the end to propose an FTA (it could not have been otherwise, since legally this decision was his to make), businessmen from Mexico and the US (an epistemic community of like-minded entrepreneurs with access to the halls of power and the media), together with Prime Ministers or presidents from other countries (yet another epistemic community of sorts) took him there.

But the story is even more complex. Salinas was in a position to respond to the factors reviewed above because domestic developments during the 1980s had

${ }^{17}$ The initiative for a US-Mexico FTA became a North American initiative when Canada, worried about investment-diversion effects (Mexico had cheaper labor costs) and its regional political influence, requested to join the negotiations. 
lifted the political and economic constraints on a more aggressive trade stance. Four again deserve mention: the arrival in government of technocrats well versed in neo-classical economics, the drive to secure access of Mexican exports to the US market, the unilateral trade liberalization Mexico implemented between 1985 and 1988, and the pressure to stabilize trade rules.

Technocrats took charge of economic policymaking in late 1982, first as a small group with president Miguel de la Madrid (1982-1988), then as the most prominent Cabinet members with Salinas (1988-1994) and Ernesto Zedillo (1994-2000). They replaced the cadre of policymakers that had recommended against Mexico's entrance to the GATT and the adoption of export-led strategy in the late 1970s. ${ }^{18}$ They also constituted an epistemic community on their own, friendly to open markets, with connections to the international financial community, able to push forward a new framework for economic policy. As observers of the integration experiences of North America and Europe, in particular the positive fate of Spain, and the export- oriented success of the Asian Tigers, they sought to modernize Mexico by emulating their experiences.

Their initial efforts in the 1980s concentrated on eliminating the antiexport bias of Mexican trade policy, while securing better terms of access of the country's exports to the US market. As their power consolidated in the 1990s, but especially as their economic program gained roots, they pushed for a more comprehensive approach: negotiate better terms of access with the US, yes, but

${ }^{18}$ The Economic Cabinet of then president J osé López-Portillo (1976-1982) was dominated by economists closer to the tradition of ECLA and Cambridge, institutions which at the time advocated more state involvement in the economy. For an exploration into the determinants of López-Portillo's decision to postpone Mexico's GATT accession see Story (1983) and FlroesQuiroga (1998). 
do the same with the rest of the country's main trading partners in Latin America, Europe and Asia (see below).

The removal of the anti-export bias started in the summer of 1985, with the replacement import permits with tariffs, and their unilateral reduction over the next three years, with the aim of establishing a "rational" structure of protection - higher tariffs for more elaborate goods. ${ }^{19}$ Almost at the same time, they negotiated Mexico's accession to the GATT, reversing the controversial decision not join in during the oil boom of the 1980s. ${ }^{20}$

In implementing this trade liberalization program they hardly had an alterantive. Strapped for cash as a consequence of the debt crisis of 1982, the government could not subsidize export programs in a significant way. Exporters could only produce badly-needed dollar revenues if their competitiveness improved through access to low-cost inputs. International financial institutions, such as the IMF and the World Bank, were hinting that a successful renegotiation of Mexico's debt would be conditioned on credible trade liberalization, which by then many understood to depend on the binding of Mexican tariffs under the GATT regime. ${ }^{21}$ And the US government, upon requests from US producers, had

\footnotetext{
${ }^{19}$ On the structure of Mexican protection at the time see De Mateo and Ten Kate (1989a, 1989b).

20 See below for determinants of this decision. Detailed acocunts of the process through which it was reached can be found in De la Madrid (1985), Flores Quiroga (1998), SECOFI (1988), Ten Kate (1992).

${ }^{21}$ Mexico signed with the IMF a Letter of Intent in April 1985 in which it committed to: (1)liberalize between 35\% and 45\% of imports before the end of 1985 -including reducing tariff levels from 10 to 7 and setting most tariffs between 10\% and 50\%; (2)grant automatic import permits of raw materials and machinery parts when the price of domestic substitutes exceed $50 \%$; and (3)allow exporters to import up to $40 \%$ of the value of their export revenues without the requirement of any permit, while letting them to import free of duties any good used as input.
} 
begun to impose countervailing duties (CVDs) on imports coming from countries that subsidized their exports, such as Mexico. ${ }^{22}$

The controversy surrounding these CVDs is particularly relevant for our story, as its outcome opened the door to the adherence of Mexico to the GATT, and eventually, to the pursuit of FTAs. Mexican producers could have disputed the imposition of CVDs, in principle, by resorting to the "injury test," which allowed exporters to show that they were not engaged in unfair trade. But the US government argued that Mexican exports were not beneficiaries to such a test, because Mexico failed to implement the provisions of the GATT Subsidies Agreement, a prominent outcome of the Tokyo Round. ${ }^{23}$

Facing pressures from Mexican exporters hurt by this change in US trade regulations, Mexican economic authorities sought some form of agreement to obtain the injury test. It came in the form of a Memorandum of Understanding between the United States and Mexico Regarding Subsidies and Countervailing Duties signed in the spring of 1985, in which Mexico explicitly renounced the use of subsidies programs to support exports. ${ }^{24}$ The only instruments left to promote exports were the elimination of import permits and the lowering of tariffs (an

\footnotetext{
${ }^{22}$ Weintraub (1990) provides a discussion of this shift in US policy. The US was also objecting Mexico's industrial promotion programs, especially in the pharmaceutical industry (Flores Quiroga, 1998).

23 The Subsidies Agreement, already incorporated into US trade legislation, established that direct export subsides constituted unfair trade, thus liable to face CVDs. An exporter from country that was a GATT contracting party could resort to the "injury test" to show that it was not relying on those subsides to gain an unfair competitive advantage, in which case the CVD would be eliminated. But an exporter from a country suspect of using subsides that was not a GATT contracting-party did not count with that line of defense.

24 The targets included credit, export, energy, and other production subsidies central to the government's industrial promotion policy. Lyman (1989) interprets this episode as an example of a conscious and successful US foreign policy directed at pushing for a transformation in Mexico's trade regime.
} 
import tariff is equivalent to an export tax), which decreased the costs of imported inputs.

Adhesion to the GATT, as many inside and outside the government realized, was all but inevitable at that point: in agreeing to remove export subsidies and unilaterally lowering tariffs, Mexico was already operating under the GATT regime, but without enjoying its benefits in the form of greater access to foreign markets. ${ }^{25}$ While the case could be made that unilateral liberalization was welfare-enhancing, it was even better to join the GATT and obtain reciprocal tariff concessions from the country's main export partners.

Mexico's move to join the GATT was soon interpreted as a sign that it was taking measures to avoid the reversal of trade reforms. ${ }^{26}$ In the 1970s the Mexican government had attempted twice to lower trade barriers, but never bound them to an international treaty. As such, its credibility in reducing trade barriers successfully was in doubt. This time it was different: no one expected Mexico to ignore its GATT commitments, as the costs in terms of reputation and financing would be very high. A more open trade regime had arrived for good.

By the time Salinas decided to propose the negotiation of a US-Mexico FTA not only was the world moving in the direction of regional blocks, but Mexican trade policy was recognizably different from that of only a few years earlier. All significant import permits had been phased out. Instead of applying an ad-hoc tariff schedule, tariffs levels were rationalized. The maximum tariff was

\footnotetext{
25 Testimony by Mexico's Trade Secretary, Héctor Hernández, at the Mexican Senate. De Mateo (1986, 1988) discusses the terms of the debate and the technical issue behind accession to the GATT at that time.

26 Ten Kate (1992a, 1992b).
} 
bound to 50\%, following GATT commitments, but in effect it declined from 100 to $20 \%$. Tariff dispersion decreased notably, with only five tariff levels left. Export subsidies had disappeared. Mexico was a GATT contracting party. And much of Mexican trade was managed through sectoral agreements with the United States. The jump from managed trade in specific sectors to freer trade in every sector ${ }^{27}$ was no longer unthinkable, even if it attempted to bring together very disparate economies.

So the trigger for Mexico's decision to negotiate NAFTA combines a governmental response to integration initiatives abroad, driven by the pressure of domestic interests as much as by independent maneuvering from like-minded economic authorities. But this response was possible because much work had been done domestically to reform the core of Mexican trade policy and the conduction of trade disputes with the United States.

Choosing additional trade partners

Negotiations for NAFTA, which began in 1990, immediately raised a new concern in Mexican policymaking circles: while the agreement would secure access to the country's exports in the US and Canadian markets, it created strong incentives for exporting only to them. At that time the expectation was that the share of Mexican exports concentrated in the US market would climb from $70 \%$ more than $80 \%$. Government officials estimated that negotiating FTAs elsewhere would help provide investors with a more geographically-neutral export

${ }^{27}$ Except petroleum, whose control the Mexican Constitution retains for the State. 
incentive, reduce the vulnerability associated with a high export concentration in just one market, and perhaps integrate productive chains between more countries. Once free trade had been adopted as the new economic paradigm, there was no reason to stop in just one country or region.

What other countries were ideal partners? From an economic viewpoint, one would expect those with the largest share of bilateral trade and potential investment flows, whose economic structure allowed for complementarities, and with a similar level of development. For Mexico in the early 1990s, the best candidates according this line of reasoning were the European Community (not yet a full-fledged Union), J apan, and to a lesser degree Latin America. Together they represented more than $90 \%$ of Mexican trade.

But the choice was neither clear-cut nor preordained. Even though Western Europe was Mexico's second largest trade and investment partner, its level of development was much higher than Mexico's, and it was on the other side of the Atlantic. Europe, moreover, was immersed in its own integration dynamic, with an eye on investment opportunities in the recently opened Eastern Block. J apan was a reliable and important trade and investment partner as well, but it was far in the Pacific and preferred multilateral to bilateral trade negotiations. For J apan an FTA was from the outset a non-starter. Brazil, Mexico's main trade partner in Latin America shared a comparable level of development, but its economic structure did not allow for significant economic complementarities. And it was focused on consolidating Mercosur, where it had a clear leadership. An FTA with Mexico was not even an afterthought. 
From a political viewpoint there were additional dilemmas. Should ideological affinity or regional balancing take precedence? If ideology mattered, the best route would be to approach Latin American countries implementing market reforms, or even European countries, whose brand of market capitalism was closer to the Mexican. If regional balancing was paramount, then it was best to approach Europe or Latin American countries concerned about the implications of Mercosur and the growing influence of Brazil. The former was a form of defensive balancing; the latter offensive.

Security also played a role, making neighboring countries particularly relevant. Assuming FTAs promoted prosperity between its partners, they could serve to reduce migration flows, illegal cross-border activities, and consolidate economic and political reforms in neighboring countries. This was the logic behind the interest of the US government in promoting an FTA with Mexico, and the logic of Mexico in promoting an FTA with Central America. ${ }^{28}$

Competitive regionalism in the legal sense became important later in the FTA strategy, to the extent that a larger number of FTAs started locking-in incentives among a large number Mexican trade partners by the late 1990s. Mexican FTAs in Latin America shared basically the same disciplines as NAFTA. It was logical to attempt extending them to multilateral negotiations for a Free Trade Agreement of the Americas (FTAA), or for the Doha Trade Round.

\footnotetext{
${ }^{28}$ Most Central American countries had suffered protracted civil wars in the previous decades. The origin of those wars was linked in part to the absence of economic opportunities. Freer trade with Mexico, a much larger market than that provided by any Central American nation to any of its neighbors, had the potencial of bringing greater wealth.
} 
The drivers of Mexico's of trade negotiations were eventually determined through the combination of design -itself a result of domestic political arrangements-, circumstance, and a degree of path dependence. Not every target country selected according to the aforementioned criteria was ready to begin an FTA negotiation with Mexico, and available resources could only be committed to a limited set of negotiations. International economic competition, domestic policy concerns, and regional balancing became preponderant factors in the early phases of the country's FTA strategy. Once a large share of trade began to take place under the framework of FTAs, international political and legal competition took greater significance.

Bear in mind that the Mexican private sector sanctioned all the choices the government made. During the NAFTA negotiations the government made sure to count with the support of the country's business associations, promoting the creation of the private sector's foreign trade steering committee (COECE, in Spanish) and the "room next door" for consultations during the actual negotiation process. Likewise, before the government launched a new trade negotiation, it always sought to obtain the compliance of COECE, so that the policy was seen as consensual rather than as imposition. For most negotiations compliance was not hard to get, since FTAs had become a standard of the new policy regime (an omnidirectional approach). Except for clear competitors, such as Brazil or South Korea, the rest of the FTAs posed relatively minor threats. Even then, the volume of trade involved outside Europe and J apan was relatively minor to create major worries among domestic producers. The biggest hurdle accepting to negotiate with the US- had already been overcome. 
The first partner chosen, and ready, for this diversification strategy was Chile, a small economy with a production structure that complemented Mexico's own (it was more geared toward agriculture than manufacturing), run by policymakers with an ideological bent similar to that of their Mexican counterparts, and less involved in the construction of a South American trade bloc as its neighbors on the other side of the Andes. Mexico-Chile FTA negotiations took place at basically the same time as the NAFTA negotiations, concluded earlier, and were ratified earlier.

Negotiating with Chile would also help to temper the reaction of other Latin American governments to Mexico's approach to the United States, which from the outset was hardly welcoming. To some in the Southern Cone, Mexico was siding with the United States, breaking the long cultural and political ties with the region as it tried to secure better trade preferences from its neighbor to the North. ${ }^{29}$ More seriously, Brazil demanded that Mexico automatically granted to the rest of the Latin American region the same trade benefits it was giving the US, in congruence with article 44 of ALADI, which requires that trade preferences extended to nonmembers should be extended to members. Mexico's government was not ready to make such a concession, and even signaled that it would leave ALADI if forced to do so. The tensions eased, but Mexico had to embark in FTA negotiations with the rest of the Latin American economies to show that it still remained committed to the reigon.

\footnotetext{
29 For example, see the statement by the presidents of Argentina, Carlos Menem, when this negotiation was announced.
} 
FTA negotiations were faster in those countries where, like Chile, greater potential for economic complementation existed, bilateral trade volumes were small, ideological affinity was more apparent, and domestic political conditions made it easier to reach an agreement: Colombia and Venezuela (which together with Mexico constituted the G-3), Bolivia, Costa Rica, and Nicaragua. Note that, at the time of the negotiations, conservative, or at least market-friendly governments were ruling these countries.

Negotiations with the rest of the Latin American countries progressed at a slower pace, or simply stalled, due to factors specific to each. In South America, Ecuador entered a period of economic and political turbulence that resulted in premature replacement of elected presidents. Peru found itself in a similar dynamic. Argentina, Brazil, Paraguay and Uruguay were immersed in the construction of MERCOSUR. Only Uruguay, sandwiched between the two giants of South America, was interested in diversifying its bets, probably concerned with counterbalancing, by negotiating an FTA with Mexico. In Central America, Panama had no urgent need for an FTA, as much world trade crossed its own country, but more importantly, was not willing to enter negotiations that required adjustments to its own tax laws, which were incompatible with the framework Mexico had adopted after it signed NAFTA. ${ }^{30}$ Guatemala, Honduras, and El Salvador had already begun to negotiate a joint FTA with Mexico, but their concern with implementing the provisions of the peace accords they had recently reached with domestic rebel groups after decades of domestic civil war, together with their insufficient expertise in this type of agreements, slowed the process

30 Panama's tax laws provide for confidentiality in terms similar to those of Switzerland. 
substantially. Negotiations nonetheless proceeded and culminated in the signing of an FTA by 2001.

By the time negotiations started with the European Union and Israel, the basic objectives of securing stable access to the country's main export market, anchoring expectations about the course of trade policy, and signaling commitment to market-friendly policies, had for all practical purposes been accomplished. NAFTA did that much. Europe could provide, as mentioned above, investments, export diversification, hopefully a counterweight to growing US influence.

The approach to Europe began in the mid-1990s. It involved a more ambitious agenda than that of the preceding FTAs. Europe wanted to include a "democratic clause," a provision that explicitly contemplated the suspension of the agreement should the parties stopped being democratic. Since European countries could not all agree to the same type of disciplines for foreign direct investment NAFTA contained, bilateral investment treaties with each relevant EU member had to be negotiated. Mexico and Europe wanted to include official development assistance as part of the framework. It was absent from NAFTA and it had shown its power to increase the economic growth rate of countries in Europe that had access to social cohesion funds. The agreement provided for the inclusion of every new member that eventually became a part of the EU, expanding automatically the number of countries with which Mexico would exchange under free trade.

As all of these agreements moved forward, efforts in Asia, then focused on Singapore and J apan, did not. The governments of Mexico and Singapore began 
to talk about the possibility of an FTA, only to find that Mexican businessmen would have none of it. They saw Singapore much in the same light as Brazil -a manufacturing powerhouse that would compete with them directly. Talks for an FTA had to be suspended.

With J apan ambivalence was the name of the game throughout 1990s. On the one hand, the Japanese government had not made up its mind about the value of negotiating FTAs, maintaining its preference for multilateral trade negotiations. The Mexican government, on the other, felt little urgency to move forward with an agreement. It had NAFTA, a network of FTAs in Latin America, and ongoing negotiations for an FTA with the European Union.

Ambivalence was affordable for a while: Japanese firms exporting to Mexico components for the in-bond industry, which in turn exported to the US, obtained special tariff treatment by the Mexican government - a NAFTA parity of sorts. As the full provisions of NAFTA were implemented, which in the end were discriminatory to countries without an FTA, the real costs of this ad-hoc accommodation became evident. J apanese firms had to deal with cumbersome administrative procedures and red-tape in both Mexico and the United States which their competitors could avoid. Pressure from Japanese investors and Mexican businessmen increased for an FTA that provided full NAfta parity.

Private sector pressure, however, was insufficient. It was until Japan, realizing that multilateral trade talks were going to proceed slowly, opted to negotiate an FTA with Singapore, that the door for concluding a negotiation with Mexico finally opened. After a long and tortuous process the two countries reached an agreement in 2004. 
By way of summary

Table 2 attempts a summary of the motives behind the selection and timing of trade partners. It identifies competitive channels of policy diffusion along three dimensions: economic, political, and legal. Economic factors prevail where a large share of Mexican trade is involved. This puts North America, the European Union, and Japan at the top of the list, since an FTA with them would cover more than $90 \%$ of Mexico's total international trade and the near totality of its FDI. Political (security) and legal factors are coded where trade covered under the prospective FTA is less than 5\% of total trade and FDI. These FTAs involve Central American, Caribbean, and Andean countries for the period 1994-1998 where Mexico has strategic interests. Legal objectives begin counting after basic trade objectives are solved with the US and the European Union, and when it made sense: with the stalling of WTO and FTAA negotiations.

\begin{tabular}{|l|l|c|c|c|}
\hline \multicolumn{5}{|c|}{ Table 2. Mexico. The drivers of competitive regionalism } \\
\hline Year & $\begin{array}{l}\text { Agreement } \\
\text { with }\end{array}$ & \multicolumn{2}{|c|}{$\begin{array}{c}\text { Competitive channels of policy } \\
\text { diffusion }\end{array}$} \\
\hline 1986 & GATT & Economic & Political & Legal \\
\hline 1992 & Chile & x & x & \\
\hline 1993 & APEC & X & & \\
\hline 1994 & $\begin{array}{l}\text { United } \\
\text { States and } \\
\text { Canada }\end{array}$ & $\mathrm{x}$ & & \\
\hline 1995 & $\begin{array}{l}\text { Colombia } \\
\text { and } \\
\text { Venezuela } \\
\text { (G-3) }\end{array}$ & & x & \\
\hline 1995 & Bolivia & & & \\
\hline
\end{tabular}




\begin{tabular}{|l|l|c|c|c|}
\hline 1995 & Costa Rica & & $\mathrm{x}$ & \\
\hline 1998 & Nicaragua & & $\mathrm{x}$ & \\
\hline 1998 & Uruguay & & $\mathrm{x}$ & $\mathrm{x}$ \\
\hline 2000 & Israel & & & \\
\hline 2000 & $\begin{array}{l}\text { European } \\
\text { Union }\end{array}$ & $\mathrm{x}$ & $\mathrm{x}$ & \\
\hline 2001 & EFTA & $\mathrm{x}$ & & $\mathrm{x}$ \\
\hline 2001 & $\begin{array}{l}\text { Guatemala, } \\
\text { Honduras, } \\
\text { El Salvador }\end{array}$ & & $\mathrm{x}$ & $\mathrm{x}$ \\
\hline 2005 & Japan & $\mathrm{x}$ & & \\
\hline
\end{tabular}

The coding, incidentally, is consistent with current Mexican FTA ventures. Having negotiated with basically all of its most important trade partners, the Mexican government has moved on to negotiate with countries whose participation in Mexican trade has increased significantly. Negotiations with South Korea as of this writing are still under way.

In sum, for Mexico the sequencing of FTA negotiations puts economic considerations first, followed by political (security) and legal criteria.

\section{Conclusions}

Four conclusions stand out:

1. Mexico's FTA strategy is undoubtedly driven by factors common to functional explanations, such as the degree or complexity of bilateral exchange, but competitive regionalism is clearly at play as well. Mexican economic authorities proposed to join the North American trade block with the explicit purpose of competing for the attraction of investments, among other reasons. In 
so doing they were strongly influenced by the domestic pro-export lobby and by the drive of its technocratic elite to emulate successful economic transformation programs elsewhere, in which strategies to integrate the domestic with the international market played a fundamental role.

2. Purely economic factors, however, did not drive Mexico's choice of trade partners, and cannot account completely for the sequence with which it conducted its trade negotiations. Concern with regional balancing, political influence, legal relevance, prosperous neighbors, and security challenges played a fundamental role. Yet these other concerns were subsidiary to economic ones: the choice of the US as the first partner responded to economic considerations more than anything else, as did the choice to negotiate with the European Union before, say, the Middle East, or with J apan rather than Malaysia.

3. International factors were necessary, but not sufficient, for the development of a strategy of competitive regionalism. Without Mexico's unilateral trade liberalization and accession to the GATT, and without the constant imposition of barriers to trade between Mexico and the US, it would have been hard for the government to justify NAFTA. Domestic support, which had to be consolidated, was crucial for the negotiations.

4. Emulation did influence the Mexican government's decisions, but it is difficult to disentangle it from the calculus of economic competition. 


\section{References}

Blanco Mendoza, H. (1994) Las Negociaciones Comerciales de México con el Mundo. México: Fondo de Cultura Económica.

Brailovsky, V. (1989) "Las Implicaciones Macroeconómicas de Pagar: La Política Económica ante la 'Crisis' de la Deuda en México, 1982-1988" in C. Bazdrech, N. Bucay, S. Loaeza and N. Lustig (eds.) México: Auge, Crisis y Ajuste. México: Fondo de Cultura Económica.

Bravo Aguilera, L. (1989a) "La Política Comercial de México y el Acuerdo General sobre Aranceles Aduaneros y Comercio," in Blanca Torres and Pamela Falk (eds.) La Adhesión de México al GATT. México: El Colegio de México.

Bravo Aguilera, L. (1989b) "La Política de Comercio Exterior de México y su Presencia en las Relaciones Comerciales con Estados Unidos," in William Glade and Cassio Luiselli (eds.) La Economía de la Interdependencia: México y Estados Unidos. Mexico: Fondo de Cultura Económica.

Casar, M.A. (1984) "PRONAFICE: Industriales y Gobierno en una Estrategia Compartida," in Política Mexicana, 1, July-August.

Casar, M. A. (1989) "Empresarios y Estado en el Gobieno de Miguel de la Madrid: En Busca de un Nuevo Acuerdo," in C. Bazdrech, N. Bucay, S. Loaeza and N. Lustig (eds.) México: Auge, Crisis y Ajuste. México: Fondo de Cultura Económica.

Cypher, J.M. (1994) "Mexico's Export Promotion Policy: Un Nuevo Patrón de Acumulación?," in P. Ganster, A.G. Espinoza, and A. Grunstein (eds.) Changes in U.S.-Mexican Relations: Beyond the Border. Mexico: Universidad Autónoma Metropolitana, PROFMEX, and ANUIES.

Del Castillo, G. (1991a) "El Tratado de Libre Comercio y las Empresas Manufactureras Mexicanas," in Comercio Exterior, 41, 7, 682-688.

Del Castillo, G. (1991b) "Institutional Concerns and Mechanisms from Tripartite Free Trade Negotiations in North America," in S.J. Tandall, H. Konrad, and S. Silverman (eds.) North America Without Borders?. Calgary: University of Calgary Press.

De la Madrid, M. (1985) Las Razones y las Obras. Crónica de Sexenio. Tercer Año. Mexico: Fondo de Cultura Económica.

De la Madrid, M. (1986) Las Razones y las Obras. Crónica de Sexenio. Cuarto Año. Mexico: Fondo de Cultura Económica. 
De la Madrid, M. (1987) Las Razones y las Obras. Crónica de Sexenio. Quinto Año. Mexico: Fondo de Cultura Económica.

De la Madrid, M. (1988) Las Razones y las Obras. Crónica de Sexenio. Sexto Año. Mexico: Fondo de Cultura Económica.

De Mateo, F. (1980). "Contribución a la Polémica sobre el GATT," Comercio Exterior, 30, 2, 111-117.

De Mateo, F. (1986) "Del ¡NO! al ¡SI! Historia de un Matrimonio por Conveniencia (México frente al GATT)," in Gustavo del Castillo (ed.) Mexico en el GATT: Ventajas y Desventajas. México: El Colegio de la Frontera Norte.

De Mateo, F. (1988) "La Política Comercial de México y el GATT," El Trimestre Económico, 217, 175-216.

Del Castillo, G. (1980) "The Generalized System of Preferences and Mexican-U.S. Relations," paper prepared for the Latin American Studies Association. Bloomington, Indiana.

Erb, G. (1989) "U.S.-Mexican Trade and Investment Agreements." Hearing on Bilateral Trade Agreements by the Subcommittee of International Trade, Committee on Finance, U.S. Senate, March 13.

Heredia, B. (1994) "Making Economic Reform Politically Viable: The Mexican Experience," in W. C. Smith, C.H. Acuña, and E.A. Gamarra (eds.) Democracy, Markets, and Structural Reform in Latin America: Argentina, Bolivia, Brazil, Chile, and Mexico. Miami, Fl.: North-South Center, University of Miami and Transaction Publishers.

Hernández Cervantes, H. (1982) "El Futuro del Comercio entre México y Estados Unidos," in IMCE (ed.) El Comercio Exterior de México. México: IMCE.

López Portillo, J . (1988) Mis Tiempos. Mexico: Fernández Editores.

Luna, M., R. Tirado, and F. Valdéz (1986) "Businessmen and Politics in Mexico," in S. Maxfield and R. Anzaldúa (eds.) Government and Private Sector in Contemporary Mexico. San Diego, CA: Center for U.S.-Mexican Studies, University of California, San Diego.

Lustig, N. (1992) Mexico: The Remaking of an Economy. Washington, D.C.: Brookings Institution.

Lyman, D. (1989) "Astucia Diplomática: Política Estadounidense para un Pacto de Subsidios Bilateral y la Entrade de México al GATT $(1980,1985), "$ in B. Torres and P. Falk (eds.) La Adhesión de México al GATT. México: El Colegio de México. 
Mexico-U.S. Business Committee (1987) Report of the Advisory Group on Capital Development for Mexico. Washington, D.C.: Mexico-U.S. Business Committe.

Mexico-U.S. Business Committee (1989a) "Testimony of Guy F. Erb. Hearing on Bilateral Trade Agreements by the Subcommittee on International Trade, Committee of Finance, U.S. Senate." March 13, 1989. Mimeo. Washington, D.C.: U.S. Council of the Mexico-U.S. Business Committee.

Mexico-U.S. Business Committee (1989b) "Options for Liberalizing U.S.-Mexico Trade and Investment." Mimeo. Washington, D.C.: U.S. Council of the MexicoU.S. Business Committee.

Nogués, J . (1986) "Nota sobre los Casos de Aranceles Compensatorios de Estados Unidos en contra de México," in Estudios Mexicanos 1, 2, 337-355.

Pastor, M. and C. Wise (1994) "The Origins and Sustainability of Mexico's Trade Policy," in International Organization, 48, 3, 459-490.

Pastor, R.A. and J. Castañeda (1988) Limits to Friendship: The United States and Mexico. NewYork, N.Y.: Knopf.

Peñaloza Webb, T. (1985) "La Adhesión de México al GATT," in Comercio Exterior, 35, 12, December, pp. 1160-1168.

Purcell, J.F. (1982) "Trade Conflicts and U.S.-Mexico Relations." San Diego, CA: Working Papers in U.S.-Mexican Studies, Program in U.S.-Mexican Studies, UCSD.

Ros, J. (1987) "Mexico from Oil Boom to the Debt Crisis: An Analysis of Policy Response to External Shocks," in R. Thorp and L. Whitehead (eds.) Latin American debt and the Adjustment Crisis. Pittsburg: University of Pittsburgh Press.

Ros, J . (1994) "On the Political Economy of Market and State Reform in Mexico," in W. C. Smith, C.H. Acuña, and E.A. Gamarra (eds.) Democracy, Markets, and Structural Reform in Latin America: Argentina, Bolivia, Brazil, Chile, and Mexico. Miami, Fl.: North-South Center, University of Miami and Transaction Publishers.

Salinas de Gortari, Carlos (2002). México: el difícil paso a la modernidad. México: Planeta.

SECOFI (1980) Concesiones Recibidas por México en el GATT," in Comercio Exterior 30, 2.

SECOFI (1985) Programa de Fomento Integral a las Exportaciones. Mimeo. 
SECOFI (1988) Apertura Comercial y Modernización Industrial. México: Cuadernos de Renovación Nacional-Fondo de Cultura Económica.

SHCP and Banco de Mexico (1985), "Carta de Intención al FMI," in Comercio Exterior, 4, 414-418.

SHCP (1988) Deuda Externa. Mexico: Cuadernos de Renovación Nacional, FCE.

Story, D. (1986) Industry, the State, and Public Policy in Mexico. Austin, TX.: University of Texas Press, 1986.

Ten Kate, A. (1992a) "Trade Liberalization and Economic Stabilization in Mexico: Lessons of Experience," in World Development 20, 659-672.

Ten Kate, A. (1992b) "El Ajuste Estructural de México. Dos Historias Diferentes," in Pensamiento Iberoamericano, 21, pp. 57-78.

Ten Kate, A. and F. de Mateo (1989a) "Apertura Comercial y Estructura de la Protección en México: Estimaciones Cuantitativas de los Ochenta," in Comercio Exterior 39, 4, 312-329.

Ten Kate, A. and F. de Mateo (1989b) "Apertura Comercial y Estructura de la Protección en México: Un Análisis de la Relación entre Ambas," in Comercio Exterior 39, 6, 497-511.

Ten Kate, A., R. Wallace, A. Warts, and M. D. Rodriguez de Wallace (1979) La Política de Protección en el Desarrollo Económico de México. Mexico: Fondo de Cultura Económica.

Torres, B., and P. Falk (1989) La Adhesión de México al GATT. México: El Colegio de México.

Vega Cánovas, G. (1983) "Las Exportaciones Mexicanas y el Neoproteccionismo Norteamericano." in L. Meyer (ed.) Mexico-Estados Unidos. Mexico: El Colegio de México.

Vega Cánovas, G., ed. (1991) México ante el Libre Comercio con América del Norte. México: El Colegio de México-Universidad Tecnológica de México.

Villarreal, R. (1976) El Desequilibrio Externo en la Industrialización de México: Un Enfoque Estructuralista, Mexico: El Colegio de México.

Weintraub, S. (1984) Free Trade between Mexico and the United States? Washington, D.C.: The Brookings Institution. 
Weintraub, S. (1989) Mexico Frente al Acuerdo de Libre Comercio CanadaEstados Unidos. Mexico: Editorial Diana.

Weintraub, S. (1990) A Marriege of Convenience: Relations between Mexico and the United States. Ney York, NY: Oxford University Press, 1990.

Zabludovsky, J . (1989) "Trade Liberalization and Macroeconomic Adjustment in Mexico, 1983-1988," Mimeo, SECOFI.

Zabludovsky, J. (1994) "Las Negociaciones del Tratado de Libre Comercio de Norte América," in Testimonios sobre el TLC. México: Grupo Editorial Miguel Angel Porrúa.

Senado de la República (1986). Consulta sobre el GATT. Mexico: Talleres Gráficos de la Nación.

(to be completed....) 
GIARI Working Paper Vol. 2008-E-12,

June.30 2008

Published by Waseda University Global COE Program

Global Institute for Asian Regional Integration (GIARI),

Waseda University, Nishiwaseda Bldg. 5F\#507 1-21-1

Nishi-waseda, Shinjuku-ku, Tokyo 169-0051 Japan

E-mail: affairs@,waseda-giari.jp

Webpage: http://www.waseda-giari.jp

Printed in Japan by International Academic Printing Co.Ltd 